\title{
Sulfuric Acid Immobilized on Silica Gel as Highly Efficient and Heterogeneous Catalyst for the One-Pot Synthesis of 2,4,5-Triaryl-1H-imidazoles
}

\author{
Behrooz Maleki $^{1 *}$, Hossein Keshvari Shirvan ${ }^{1}$, Fereshteh Taimazi ${ }^{1}$, Elahe Akbarzadeh ${ }^{2}$ \\ ${ }^{1}$ Department of Chemistry, Sabzevar Tarbiat Moallem University, Sabzevar, Iran \\ ${ }^{2}$ Department of Chemistry, Tarbiat Moallem University, Tehran, Iran \\ Email: *maleki@sttu.ac.ir
}

Received January 4, 2012; revised February 7, 2012; accepted February 15, 2012

\begin{abstract}
Application of sulfuric acid immobilized on silica gel as an efficient and benign catalyst has been explored in the synthesis of 2,4,5-Triaryl-1H-imidazoles via condensation reaction of benzil or benzoin, aldehyde and ammonium acetate. The key advantages of this process are high yields, cost effectiveness of catalyst, easy work-up, purification of products by non-chromatographic method and the reusability of the $\mathrm{H}_{2} \mathrm{SO}_{4} \cdot \mathrm{SiO}_{2}$ catalyst.
\end{abstract}

Keywords: 2,4,5-Trisubstituted Imidazoles; Solvent-Free Synthesis; Multicomponent Reaction; Silica-Supported Sulfuric Acid; Heterogeneous Catalyst

\section{Introduction}

Multicomponent reactions (MCRs) have drawn great interest enjoying an outstanding status in modern organic synthesis and medicinal chemistry because they are onepot processes bringing together three or more components and show high atom economy and high selectivity [1,2].

MCRs have great contribution in convergent synthesis of complex and important organic molecules from simple and readily available starting materials, and have emerged as powerful tools for drug discovery $[3,4]$. The imidazole nucleus is a fertile source of biologically important molecules. Compounds containing imidazole moiety have many pharmacological properties and play important roles in biochemical processes. They are well known as inhibitors of P38MAP kinase, fungicides, herbicides, antiinflammatory agents, antithrombotic agents, plant growth regulators and therapeutic agents. In addition, they are used in photography as photosensitive compounds. Some substituted triarylimidazoles are selective antagonists of the glucagons receptor and inhibitors of IL-1 biosynthesis [5]. Radziszewski and Jaap proposed the first synthesis of the imidazole core in 1882, starting from 1,2-dicarbonyl compounds, aldehydes and ammonia to obtain 2,4,5-triphenylimidazole [6,7]. There are several methods for the synthesis of 2,4,5-triarylimidazoles using $\mathrm{H}_{3} \mathrm{PO}_{4} \cdot 12 \mathrm{MoO}_{3} \cdot 24 \mathrm{H}_{2} \mathrm{O}, \mathrm{KH}_{2} \mathrm{PO}_{4}$ [8], catalyst-free under microwave irradiation [9,10], ionic liquid (1-n-butyl and

*Corresponding author. 1,3-di-butyl imidazolium salts) [11], ceric (IV) ammonium nitrate (CAN) [12], oxalic acid [13], $\mathrm{Eu}(\mathrm{OTf})_{3}$ [14], [Hmim] $\mathrm{HSO}_{4}$ [15], $\mathrm{ZrCl}_{4}$ [16], $\mathrm{Yb}(\mathrm{OTf})_{3}$ [17], $\mathrm{NiCl}_{2} \cdot 6 \mathrm{H}_{2} \mathrm{O}$ [18], sodium bisulfate [19], iodine [20], nanocrystalline magnesium Oxide [21], oxalic acid [22], silica sulfuric acid [23], acetic acid [24], L-proline [25], PEG-400 [26], $\mathrm{Cu}(\mathrm{TFA})_{2}$ [27], tetrabutylammoniumbromide (TBAB) [28], $\left(\mathrm{NH}_{4}\right)_{6} \mathrm{Mo}_{7} \mathrm{O}_{24} \cdot 4 \mathrm{H}_{2} \mathrm{O}$ [29], $\mathrm{InCl}_{3} \cdot 6 \mathrm{H}_{2} \mathrm{O}$ [30], $\mathrm{Zr}(\mathrm{acac})_{4}$ [31], anhydrous $\mathrm{FePO}_{4}$ [32] and uranyl nitrate hexahydrate $\left[\mathrm{UO}_{2}\left(\mathrm{NO}_{3}\right)_{2} \cdot 6 \mathrm{H}_{2} \mathrm{O}\right]$ supported on acidic alumina [33].

Many of these methods, however, suffer from longer reaction times, unsatisfactory yields, difficult workup, and excessive use of reagents and catalyst. It is therefore important to find more convenient methods for the preparation of these compounds. Therefore, the development of a new mild method to overcome these disadvantages still remains a challenge for organic chemists. One of the aims we have in mind is to introduce a new catalyst for synthesis of 2,4,5-trisubstituted imidazoles with cost effectiveness and mild condition in high yields.

\section{Result and Discussion}

Several methods are used in the synthesis of these trisubstituted imidazoles and their derivatives. In addition, the synthesis of these heterocycles has been usually carried out in polar organic solvents such as ethanol, methanol, acetic acid, DMF and DMSO leading to complex isolation and recovery procedures. These processes also gene- 
rate waste containing catalyst and solvent, which have to be recovered, treated and disposed of. The toxicity and volatile nature of many organic solvents, particularly chlorinated hydrocarbons that are widely used in huge amounts for organic reactions have posed a serious threat to the environment [34]. Thus, design of solvent-free catalytic reaction has received tremendous attention in recent times in the area of green synthesis [35].

Solid acids and especially those based on micelletemplate silica's and other mesoporous high surface area support materials are beginning to play a significant role in the greening of fine and specialty chemicals manufacturing processes. A wide range of important organic reactions can be efficiently catalyzed by these materials, which can be designed to provide different types of acidity as well as high degrees of reaction selectivity. The solid acids generally have high turnover numbers and can be easily separated from the organic components [36,37]. In recent years the $\mathrm{H}_{2} \mathrm{SO}_{4}$ immobilized on $\mathrm{SiO}_{2}$ was used as a catalyst for synthesis of organic compounds [38-42]. In this work, we report the solvent-free synthesis of 2,4,5-trisubstituted imidazoles using $\mathrm{H}_{2} \mathrm{SO}_{4}$ immobilized on $\mathrm{SiO}_{2}$ as a catalyst under classical heating (Scheme 1).

Efficiency of this reaction is mainly affected by the amount of catalyst, temperature and reaction time. For getting the best conditions, initially we started the condensation of benzil (1 mmol), 4-chloro benzaldehyde (1 $\mathrm{mmol})$ and ammonium acetate $(5 \mathrm{mmol})$ in the presence of $\mathrm{H}_{2} \mathrm{SO}_{4}$ immobilized on $\mathrm{SiO}_{2}(0.005 \mathrm{gr})$ as a catalyst at $100^{\circ} \mathrm{C}$ for $1 \mathrm{~h}$, which led to low yield (40\%) of 2,4, 5 -trisubstituted imidazole (Table 1, entry 1 ). To enhance the yield of the desired product the temperature of the reaction was increased to $120^{\circ} \mathrm{C}$ (entry 2, 3). With increasing the temperature, the productivity of the reaction increased but was not very high. Then, it was thought worthwhile to carry out the reaction in the presence of higher amount of the catalyst (entry 4, 5). As indicated in Table 1, Maximum yield was obtained (94\%) when the reaction was loaded with $0.01 \mathrm{gr}$ of the catalyst at the $110^{\circ} \mathrm{C}$. A further increasing of catalyst loading does not affect the yield (entry 6).

After optimizing the conditions, we applied this cata- lyst for synthesis of trisubstituted imidazoles by using different aromatic aldehydes with a wide range of ortho-, meta- and para-substitutions under solvent-free classical heating conditions to establish the catalytic importance of $\mathrm{H}_{2} \mathrm{SO}_{4}$ immobilized on $\mathrm{SiO}_{2}$ for this reaction.

Generally, the synthetic procedure involves stirring the mixture of aldehyde $(1 \mathrm{mmol})$, benzil (1 mmol), ammonium acetate $(5 \mathrm{mmol})$ and $\mathrm{H}_{2} \mathrm{SO}_{4}$ immobilized on $\mathrm{SiO}_{2}$ (0.01 gr) for $45-60 \mathrm{~min}$ at $110^{\circ} \mathrm{C}$. The corresponding results are given in Table 2 . We found that the reaction proceeded very efficiently either electron-releasing or electron-withdrawing substituents on aryl ring of aldehyde.

Also, due to direct use of benzoin rather than benzil in the synthesis of imidazoles a significant improvement in the synthesis toward the greener chemistry is represented. We have repeated the reaction with benzoin instead of benzil and the desired product has been efficiently produced. As indicated in Table 2, when we used benzoin instead of benzil, the reaction time increased and also the yield of the reaction decreased partially.

Possible mechanism for the sulfuric acid immobilized on silica gel catalysed synthesis of trisubstituted imidazoles has been proposed in Scheme 2 .

In summary, this paper describes a convenient and efficient process for the Solvent-free synthesis of trisubstituted imidazoles through the three-components coupling of benzil or benzoin, aldehydes and ammonium acetate using $\mathrm{H}_{2} \mathrm{SO}_{4}$ immobilized on $\mathrm{SiO}_{2}$ as a catalyst. Reaction profile is very clean and no side products are formed. All the synthesized imidazoles have been characterized on the basis of elemental and spectral studies. We believe that this procedure is convenient, economic, and a userfriendly process for the synthesis of trisubstituted imidazoles of biological and medicinal importance.

Also, we investigated the reusability and recycling effect of $\mathrm{H}_{2} \mathrm{SO}_{4} \cdot \mathrm{SiO}_{2}$ catalyst in these reactions. At the end of each reaction, the catalyst was filtered, washed with diethyl ether, dried at $120^{\circ} \mathrm{C}$ for $3 \mathrm{~h}$, and reused in a subsequent reaction cycle. The recycled catalyst was employed consecutively for three reactions and no significant loss in its efficiency was observed (Table 2. 2a, 2d,

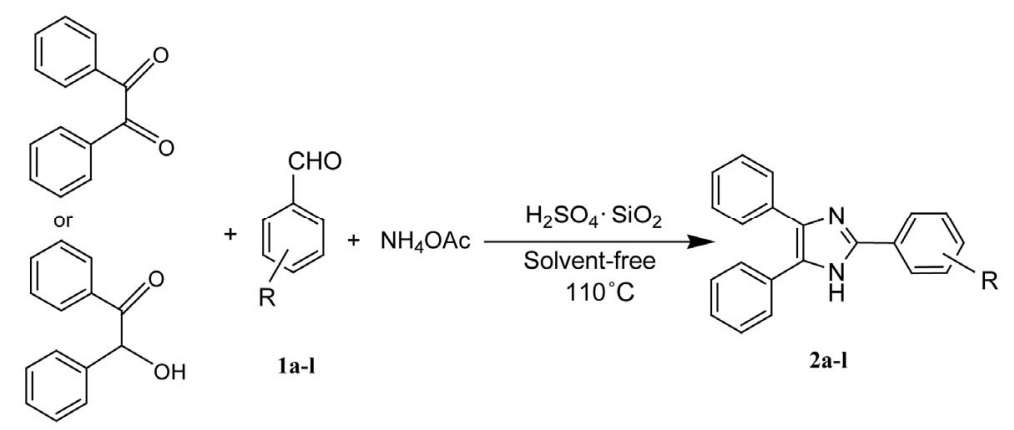

Scheme 1. Sulfuric acid immobilized on silica gel catalysed synthesis of 2,4,5-trisubstituted imidazole. 


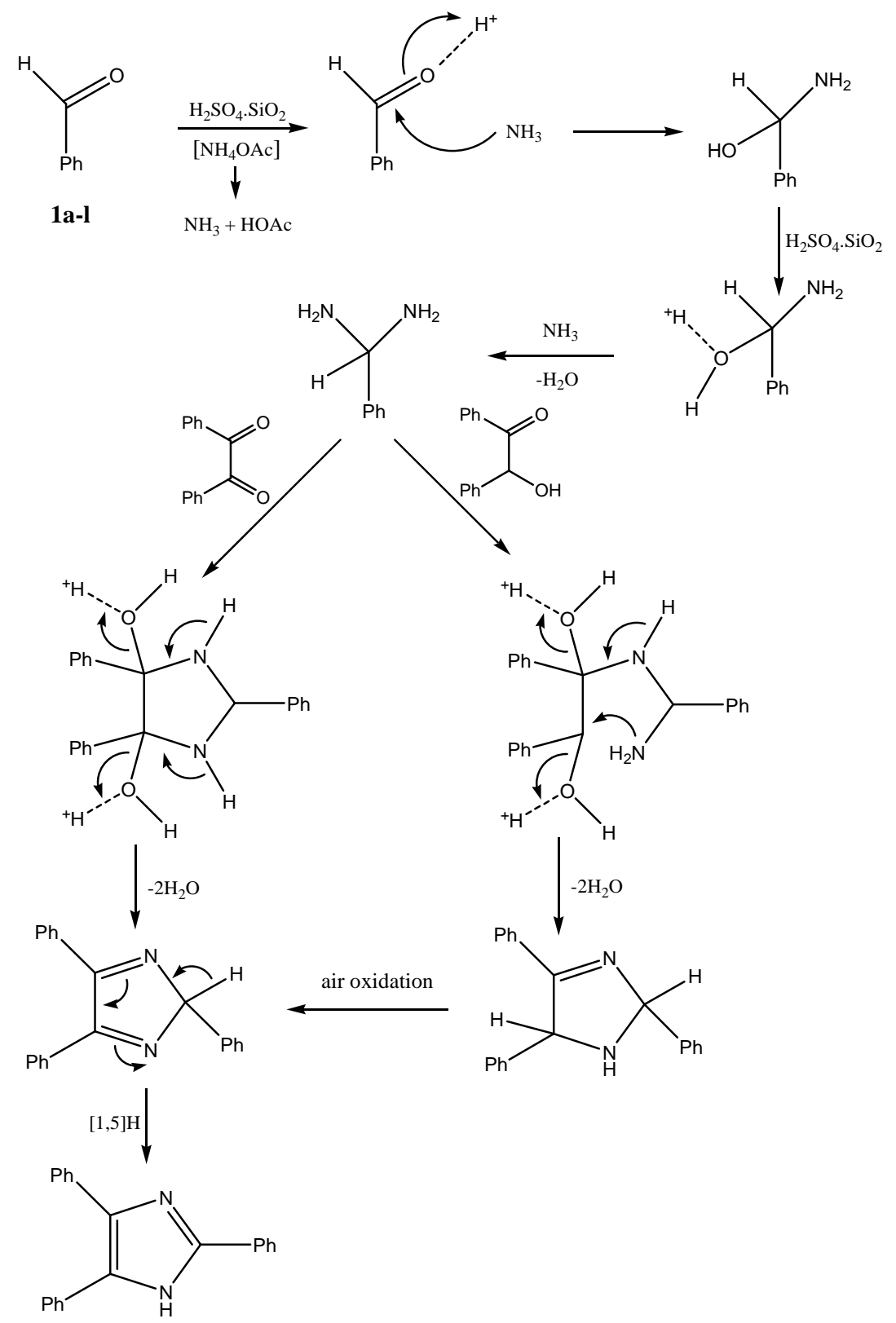

2a-I

Scheme 2. Probable mechanism for the formation of triarylimidazoles using benzil or benzoin, ammonium acetate, aromatic aldehydes using sulfuric acid immobilized on silica gel as catalyst.

Table 1. Optimization one-pot synthesis of trisubstituted imidazoles under classical heating conditions ${ }^{\mathrm{a}}$.

\begin{tabular}{ccccc}
\hline Entry & $\mathrm{H}_{2} \mathrm{SO}_{4} \cdot \mathrm{SiO}_{2}(\mathrm{gr})$ & $\mathrm{T}\left({ }^{\circ} \mathrm{C}\right)$ & Time(min) & Yield \\
\hline 1 & 0.005 & 100 & 60 & 40 \\
2 & 0.005 & 110 & 60 & 63 \\
3 & 0.005 & 120 & 60 & 63 \\
4 & 0.008 & 110 & 60 & 70 \\
5 & 0.01 & 110 & 60 & 94 \\
6 & 0.015 & 110 & 60 & 90 \\
\hline
\end{tabular}

${ }^{\mathrm{a}}$ Benzil (1 mmol), 4-chloro benzaldehyde (1 mmol) and ammonium acetate (5 mmol). 
Table 2. Synthesis of 2,4,5-triaryl-1H-imidazoles (2a-l) using $\mathrm{H}_{2} \mathrm{SO}_{4}$ - $\mathrm{SiO}_{2}(0.01 \mathrm{gr})$ under solvent-free conditions.

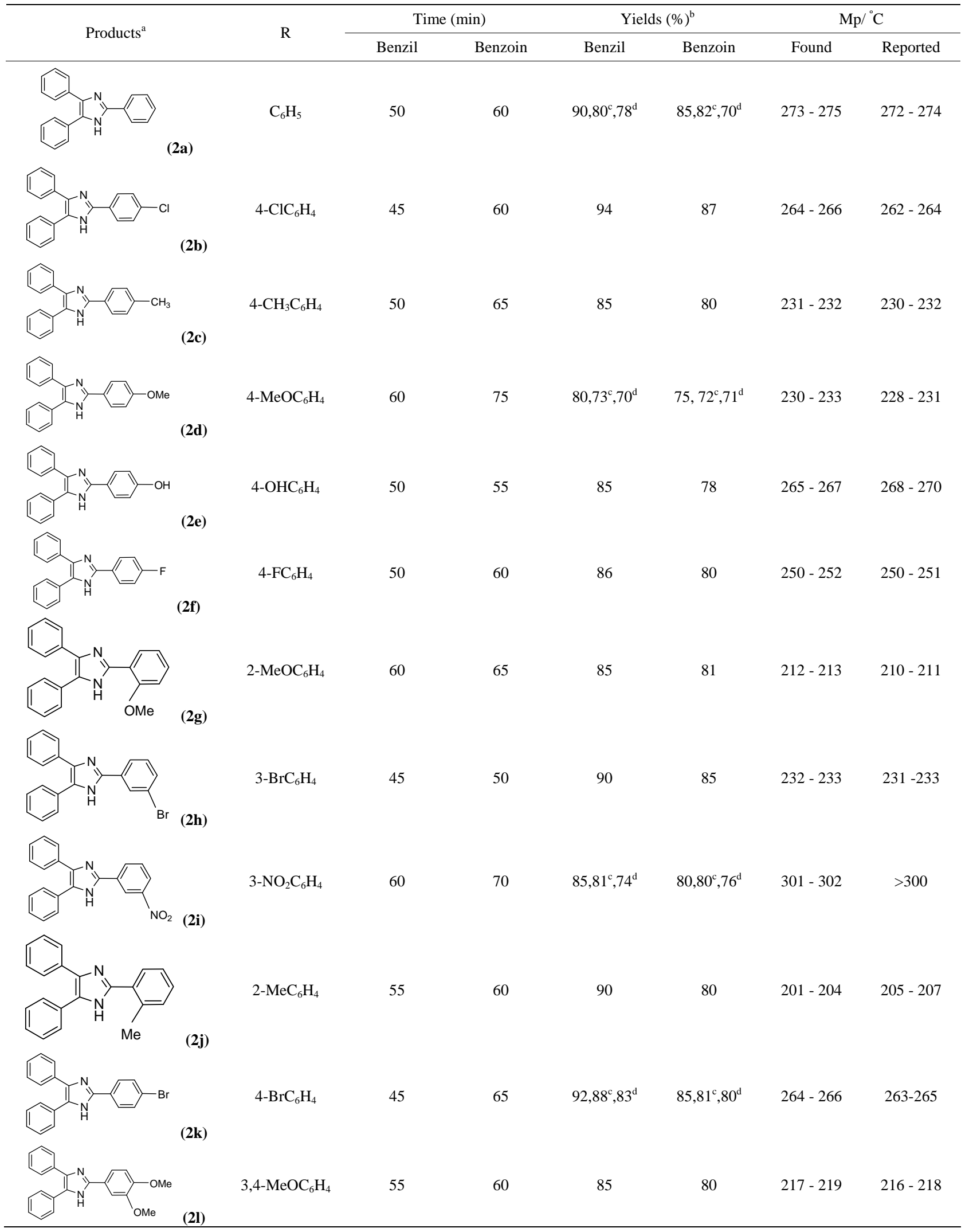

${ }^{\mathrm{a}}$ All the isolated products were characterized on the basis of their physical properties and IR, ${ }^{1} \mathrm{H}$-and ${ }^{13} \mathrm{C}$-NMR spectral analysis and by direct comparison with authentic materials; ${ }^{\mathrm{b}}$ Isolated yields. ${ }^{\mathrm{c}}$ Second run with the used catalyst. ${ }^{\mathrm{d}}$ Third run with the used catalyst. 
$2 \mathbf{i}$ and $2 \mathbf{k})$.

\section{Experimental}

\subsection{Instruments and Characterization}

Melting points were measured with an Electrothermal 9100 apparatus. IR spectra were recorded with a Varian 3100 FTIR spectrometer. CHN analyses were performed on Exeter Analytical Inc. "Model CE-400 CHN Analyzer". ${ }^{1} \mathrm{H}$ and ${ }^{13} \mathrm{C}$ NMR spectra were recorded with a BRUKER DRX-400 AVANCE spectrometer at $298^{\circ} \mathrm{K}$ and $75.47 \mathrm{MHz}$, respectively. NMR spectra were obtained on solutions in DMSO- $\mathrm{d}_{6}$. All the products are known compounds, which were characterized by IR and ${ }^{1} \mathrm{H}$ NMR spectral data and their melting points were compared with literature reports.

\subsection{Preparation of the $\mathrm{H}_{2} \mathrm{SO}_{4} \cdot \mathrm{SiO}_{2}$ Catalyst}

To a slurry of silica gel (10 g, 200 - 400 mesh) in dry diethyl ether $(50 \mathrm{ml})$ was added concentrated $\mathrm{H}_{2} \mathrm{SO}_{4}$ (3 $\mathrm{ml}$ ) with shaking for $5 \mathrm{~min}$. The solvent was evaporated under reduced pressure to obtain dry $\mathrm{H}_{2} \mathrm{SO}_{4} \cdot \mathrm{SiO}_{2}$ catalyst which was then heated at $120^{\circ} \mathrm{C}$ for $3 \mathrm{~h}$.

\subsection{General Procedure for Preparation of 2a-I}

A mixture of aldehyde ( $1 \mathrm{mmol})$, benzil or benzoin (1 mmol), ammonium acetate $(5 \mathrm{mmol})$ and $\mathrm{H}_{2} \mathrm{SO}_{4} \cdot \mathrm{SiO}_{2}$ ( $0.01 \mathrm{gr})$, as a catalyst, in a $20 \mathrm{ml}$ glass tube was stirred at $110^{\circ} \mathrm{C}$ for $45-75 \mathrm{~min}$. After completion of the reaction, the reaction was cooled to room temperature and solid materials were washed with water and the solvent was evaporated to give the crude product. For further purification it was recrystallized from ethanol $96 \%$ to afford pure product.

\subsection{The Spectral Data for Selected Compound}

2,4,5-Triphenyl-1H-imidazole (2a): $\mathrm{Mp} 273^{\circ} \mathrm{C}-275^{\circ} \mathrm{C}$. FTIR $\left(\mathrm{KBr}, \mathrm{cm}^{-1}\right)$ : 3451, 2856, 1636, 1490. ${ }^{1} \mathrm{H}$ NMR (400 MHz, DMSO- $\mathrm{d}_{6}$ ): $\delta=12.69$ (s, 1H), 8.09 (d, 2H), 7.56 - 7.22 (m, 13H). ${ }^{13} \mathrm{C}$ NMR (75 MHz, DMSO-d 6 ) $\delta$ : 145.6, 137.2, 135.2, 131.2, 130.4, 128.7, 128.5, 128.3, 128.2, 127.8, 127.2, 126.6, 125.3.

2-(4-Chlorophenyl)-4,5-diphenyl-1H-imidazole (2b): $\mathrm{Mp} 264^{\circ} \mathrm{C}-266^{\circ} \mathrm{C}$. FTIR $\left(\mathrm{KBr}, \mathrm{cm}^{-1}\right)$ : 3452, 3065, 1635, 1323. ${ }^{1} \mathrm{H}$ NMR (400 MHz, DMSO- $\left.\mathrm{d}_{6}\right): \delta=12.78(\mathrm{~s}, 1 \mathrm{H})$, 8.11 (d, 2H), $7.56-7.23$ (m, 12H). ${ }^{13} \mathrm{C}$ NMR (75 MHz, DMSO-d $\left.\mathrm{d}_{6}\right) \delta: 146.3,130.3,129.9,129.2,128.5,127.4$, 127.0, 126.4, 125.5, 125.2, 123.3, 116.3.

4,5-Diphenyl-2-p-tolyl-1H-imidazole (2c): $\mathrm{Mp} 231^{\circ} \mathrm{C}$ $232^{\circ} \mathrm{C}$. FTIR (KBr, cm ${ }^{-1}$ ): 3449, 3034, 1611, 1495, 1320. ${ }^{1} \mathrm{H}_{\mathrm{NMR}}\left(400 \mathrm{MHz}, \mathrm{DMSO}-\mathrm{d}_{6}\right.$ ): $\delta=12.59$ (s, $\left.1 \mathrm{H}\right), 7.98$ (d, 2H), 7.54 - 2.21 (m, 12H), 2.35 (s, 3H). ${ }^{13} \mathrm{C}$ NMR (75 MHz, DMSO- $\mathrm{d}_{6}$ ) $\delta$ : 145.6, 137.6, 136.9, 135.2, 131.1,
129.2, 128.6, 128.3, 128.1, 127.9, 127.6, 127.0, 126.4, 125.1, 20.8.

2-(4-Methoxyphenyl)-4,5-diphenyl-1H-imidazole (2d): $\mathrm{Mp} 230^{\circ} \mathrm{C}-233^{\circ} \mathrm{C}$. FTIR (KBr, cm $\left.{ }^{-1}\right)$ : 3425, 3029, 2956 , 1610, 1495, 1249. ${ }^{1} \mathrm{HNMR}\left(400 \mathrm{MHz}, \mathrm{DMSO}-\mathrm{d}_{6}\right): \delta=$ $12.50(\mathrm{~s}, 1 \mathrm{H}), 8.03(\mathrm{~d}, 2 \mathrm{H}), 7.50-7.33(\mathrm{~m}, 10 \mathrm{H}), 7.05(\mathrm{~d}$, $2 \mathrm{H}), 3.82$ (s, 3H). ${ }^{13} \mathrm{C}$ NMR $(75 \mathrm{MHz}$, DMSO-d 6 ) $\delta$ : 159.5, 145.7, 128.4, 127.7, 126.8, 123.1, 114.1, 55.2.

2-(4-Fluorophenyl)-4,5-diphenyl-1H-imidazole (2f): $\mathrm{Mp} 250^{\circ} \mathrm{C}-252^{\circ} \mathrm{C}$. FTIR $\left(\mathrm{KBr}, \mathrm{cm}^{-1}\right)$ : 3316, 2993, 2470, 1660, 1210, 1169, 874, 719, 639. ${ }^{1} \mathrm{H}$ NMR (400 MHz, DMSO-d $\left.\mathrm{d}_{6}\right): \delta=12.82(\mathrm{~s}, 1 \mathrm{H}), 8.28$ (d, 2H), $7.22-7.55$ $(\mathrm{m}, 10 \mathrm{H}), 7.03(\mathrm{~d}, 2 \mathrm{H}) .{ }^{13} \mathrm{C}$ NMR (75 MHz, DMSO-d $\left.\mathrm{d}_{6}\right) \delta$ : 165.4, 137.3, 131.1, 129.8, 128.9, 127.7, 127.2, 126.6, 125.9, 125.5, 124.1, 117.4 .

2-(2-Methoxyphenyl)-4,5-diphenyl-1H-imidazole (2g): Mp $212^{\circ} \mathrm{C}-213^{\circ} \mathrm{C}$. FTIR (KBr, cm $\left.{ }^{-1}\right): 3437,3033,2950$, 1615, 1498. ${ }^{1} \mathrm{H}$ NMR (400 MHz, DMSO-d 6 ): $\delta=11.82$, (s, 1H), 8.02 (d, 1H), 7.53 - 7.07 (m, 13H), 3.92 (s, 3H). ${ }^{13} \mathrm{C}$ NMR $\left(75 \mathrm{MHz}\right.$, DMSO-d $\left.{ }_{6}\right) \delta: 158.2,146.2,128.3$, 127.5, 125.4, 123.8, 115.4, 55.3.

2-(3-Nitrophenyl)-4,5-diphenyl-1H-imidazole (2i): Mp $301^{\circ} \mathrm{C}-302^{\circ} \mathrm{C}$. FTIR $\left(\mathrm{KBr}, \mathrm{cm}^{-1}\right): 3448,3068,1526$, 1350. ${ }^{1} \mathrm{H}$ NMR (400 MHz, DMSO-d $\left.\mathrm{d}_{6}\right): \delta=13.10(\mathrm{~s}, 1 \mathrm{H})$, $8.95(\mathrm{~s}, 1 \mathrm{H}), 8.53(\mathrm{~d}, 1 \mathrm{H}), 8.23(\mathrm{~d}, 1 \mathrm{H}), 7.81(\mathrm{~d}, 1 \mathrm{H})$, 7.54 - 7.33 (m, 10H). ${ }^{13} \mathrm{C}$ NMR (75 MHz, DMSO-d 6 ) $\delta$ : $148.4,143.4,131.8,131.2,130.4,128.7,128.4,127.1$, 122.6, 119.4 .

\section{Conclusion}

We have been able to introduce an efficient and environmentally friendly approach for the synthesis of biologically active trisubstituted imidazoles via condensation of benzil or benzoin with various aromatic aldehydes and ammonium acetate using sulfuric acid immobilized on silica gel as a catalyst. High yields, easy work-up, purification of compounds by non-chromatographic method (crystallization only) and the reusability of the $\mathrm{H}_{2} \mathrm{SO}_{4} \cdot \mathrm{SiO}_{2}$ catalyst are the key advantages of this method.

\section{REFERENCES}

[1] D. M. D’Souza and T. J. J. Mueller, "Multi-Component Syntheses of Heterocycles by Transition-Metal Catalysis,” Chemical Society Reviews, Vol. 36, No. 7, 2007, pp. 1095-1108. doi:10.1039/b608235c

[2] A. Domling, "Recent Developments in Isocyanide Based Multicomponent Reactions in Applied Chemistry," Chemical Reviews, Vol. 106, 2006, pp. 17-89. doi:10.1021/cr0505728

[3] X. Yu, X. Pan and J. Wu, “An Efficient Route to Diverse $H$-pyrazolo[5,1-a]isoquinolines via Sequential Multi-Component/Cross-Coupling Reactions," Tetrahedron, Vol. 67, No. 6, 2011, pp. 1145-1149. doi:10.1016/j.tet.2010.12.005 
[4] C. Kalinski, H. Lemoine, J. Schmidt, C. Burdack, J. Kolb and M. Umkehrer, "Multicomponent Reactions as a Powerful Tool for Generic Drug Synthesis,” Synthesis, Vol. 24, 2008, pp. 4007-4011. doi:10.1055/s-0028-1083239

[5] L. S. Gadekar, S. R. Mane, S. S. Katkar, B. R. Arbad and M. K. Lande, "Scolecite as an Efficient Heterogeneous Catalyst for the Synthesis of 2,4,5-Triarylimidazoles," Central European Journal of Chemistry, Vol. 7, 2009, pp. 550-554. doi:10.2478/s11532-009-0050-y

[6] B. Radziszewski, "Ueber die Constitution des Lophins und verwandter Verbindungen," Chemische Berichte, Vol. 15, 1882, pp. 1493-1496. doi:10.1002/cber.18820150207

[7] F. Japp and H. Robinson, "Beziehungen der Molekularvolumina zur Atomverkettung,” Chemische Berichte, Vol. 15, 1882, pp. 1268-1270. doi:10.1002/cber.188201501272

[8] R. S. Joshi, P. G. Mandhane, M. U. Shaikh, R. S. Kale and C. H. Gill, "Potassium Dihydrogen Phosphate Catalyzed One-Pot Synthesis of 2,4,5-Triaryl-1H-imidazoles," Chinese Chemical Letters, Vol. 21, No. 4, 2010, pp. 429432. doi:10.1016/j.cclet.2009.11.012

[9] J. F. Zhou, X. G. Gong, H. Q. Zhu and F. X. Zhu, "Solvent-Free and Catalyst-Free Method for the Synthesis of 2,4,5-Triarylimidazoles under Microwave Irradiation," Chinese Chemical Letters, Vol. 20, No. 10, 2009, pp. 1198-1120. doi:10.1016/j.cclet.2009.05.027

[10] J. F. Zhou, G. X. Gong, X. J. Sun and Y. L. Zhu, "Facile Method for One-Step Synthesis of 2,4,5-Triarylimidazoles under Catalyst-Free, Solvent-Free, and MicrowaveIrradiation Conditions," Synthetic Communications, Vol. 40, 2010, pp.1134-1141. doi:10.1080/00397910903043025

[11] S. A. Siddiqui, U. C. Narkhede, S. S. Palimkar, T. Daniel, R. J. Lahoti and K. V. Srinivasan, "Room Temperature Ionic liquid Promoted Improved and Rapid Synthesis of 2,4,5-Triaryl Imidazoles from Aryl Aldehydes and 1,2Diketones or $\alpha$-Hydroxyketone," Tetrahedron, Vol. 61, 2005, pp. 3539-3544. doi:10.1016/j.tet.2005.01.116

[12] K. F. Shelke, S. B. Sapkal and M. S. Shingare, "Ultrasound-Assisted One-Pot Synthesis of 2,4,5-Triarylimidazole Derivatives Catalyzed by Ceric (IV) Ammonium Nitrate in Aqueous Media," Chinese Chemical Letters, Vol. 20, 2009, pp. 283-286. doi:10.1016/j.cclet.2008.11.033

[13] J. Sangshetti, N. Kokare, S. Kotharkara and D. J. Shinde, "One-Pot Efficient Synthesis of 2-Aryl-1-arylm ethyl-1Hbenzimidazoles and 2,4,5-Triaryl-1H-imidazoles Using Oxalic Acid Catalyst," Synthesis, No. 18, 2007, pp. 2829-2834.

[14] C. Yu, M. Lei, W. Su and Y. Xie, "Europium TriflateCatalyzed One-Pot Synthesis of 2,4,5-Trisubstituted$1 \mathrm{H}$-imidazoles via a Three-component Condensation," Synthetic Communications, Vol. 37, 2007, pp. 3301-3308. doi:10.1080/00397910701483589

[15] A. R. Khosropour, "Synthesis of 2,4,5-Trisubstitute dimidazoles Catalyzed by $[\mathrm{Hmim}] \mathrm{HSO}_{4}$ as a Powerful Brönsted Acidic Ionic liquid," Canadian Journal of Chemistry, Vol. 86, 2008, pp. 264-269.

doi:10.1139/v08-009
[16] G. V. M. Sharma, Y. Jyothi and P. S. Lakshmi, "Efficient Room-Temperature Synthesis of Tri- and Tetrasubstituted Imidazoles Catalyzed by ZrCl4," Synthetic Communications, Vol. 36, No. 19-21, 2006, pp. 2991-2996. doi:10.1080/00397910600773825

[17] L. M. Wang, Y. H. Wang, H. Tian, Y. Yao, J. Shao and B. Liu, "Ytterbium Triflate as an Efficient Catalyst for One-Pot Synthesis of Substituted Imidazoles Through Three-Component Condensation of Benzil, Aldehydes and Ammonium Acetate," Journal of Fluorine Chemistry, Vol. 127, No. 12, 2006, pp. 1570-1573. doi:10.1016/j.jfluchem.2006.08.005

[18] M. M. Heravi, K. Bakhtiari, H. A. Oskooie and S. Taheri, "Synthesis of 2,4,5-Triaryl-Imidazoles Catalyzed by $\mathrm{NiCl}_{2} \cdot 6 \mathrm{H}_{2} \mathrm{O}$ Under Heterogeneous System," Journal of Molecular Catalysis A: Chemical, Vol. 263, No. 1-2, 2007, pp. 279-281. doi:10.1016/j.molcata.2006.08.070

[19] J. N. Sangshetti, D. B. Shinde, N. D. Kokare and S. A. Kotharkar, "Sodium Bisulfite as an Efficient and Inexpensive Catalyst for the One-Pot Synthesis of 2,4,5-Triaryl-1H-imidazoles from Benzil or Benzoin and Aromatic Aldehydes,” Monatshefte für Chemie, Vol. 139, No. 2, 2008, pp. 125-127. doi:10.1007/s00706-007-0766-3

[20] M. Kidwai, P. Mothsra, V. Bansal and R. Goyal, "Efficient Elemental Iodine Catalyzed One-Pot Synthesis of 2,4,5-Triarylimidazoles," Monatshefte für Chemie, Vol. 137, No. 9, 2006, pp. 1189-1194. doi:10.1007/s00706-006-0518-9

[21] J. Safari, S. D. Khalili, M. Rezaei, S. H. Banitaba and F. Meshkani, "Nanocrystalline Magnesium Oxide: A Novel and Efficient Catalyst for Facile Synthesis of 2,4,5Trisubstitutedimidazole Derivatives,” Monatshefte für Chemie, Vol. 141, No. 12, 2010, pp. 1339-1345. doi:10.1007/s00706-010-0397-y

[22] N. D. Kokare, J. N. Sangshetti and D. B. Shinde, "OnePot Efficient Synthesis of 2-Aryl-1-Arylmethyl- 1h-Benzimidazoles and 2,4,5-Triaryl-1h-Imidazoles Using Oxalic Acid Catalyst,” Synthesis, No. 18, 2007, pp. 28292834.

[23] A. Shaabani and A. Rahmati, "Silica Sulfuric Acid as an Efficient and Recoverable Catalyst for the Synthesis of Trisubstituted Imidazoles,” Journal of Molecular Catalysis A: Chemical, Vol. 249, No. 1-2, 2006, pp. 246-248. doi:10.1016/j.molcata.2006.01.006

[24] J. Wang, R. Mason, D. V. Derveer, F. Feng and X. R. Bu, "Convenient Preparation of a Novel Class of Imidazo[1,5-a]pyridines: Decisive Role by Ammonium Acetate in Chemoselectivity," Journal of Organic Chemistry, Vol. 68, No. 13, 2003, pp. 5415-5418. doi:10.1021/jo0342020

[25] S. Samai, G. C. Nandi, P. Singh and M. S. Singh, "L-Proline: An Efficient Catalyst for the One-Pot Synthesis of 2,4,5-Trisubstituted and 1,2,4,5-Tetrasubstituted Imidazoles," Tetrahedron, Vol. 65, No. 49, 2009, pp. 10155-10161. doi:10.1016/j.tet.2009.10.019

[26] X. C. Wang, H. P. Gong, Z. J. Quan, L. Li and H. L. Ye, "PEG-400 as an Efficient Reaction Medium for the Synthesis of 2,4,5-Triaryl-1H-Imidazoles and 1,2,4,5-Tetraaryl-1H-Imidazoles,” Chinese Chemical Letters, Vol. 20, 
2009, pp. 44-47. doi:10.1016/j.cclet.2008.10.005

[27] D. Song, C. Liu, S. Zhang and D. Luo, “One-Pot Synthesis of 2,4,5-Triarylimidazoles Catalyzed by Copper (II) Trifluoroacetate under Solvent-Free Conditions," Synthesis and Reactivity in Inorganic, Metal-Organic, and Nano-Metal Chemistry, Vol. 40, No. 3, 2010, pp. 145147.

[28] M. V. Chary, N. C. Keerthysri, S. V. N. Vupallapati, N. Lingaiah and S. Kantevari, "Tetrabutylammoniumbromide (TBAB) in Isopropanol: An Efficient, Novel, Neutral and Recyclable Catalytic System for the Synthesis of 2,4,5-Trisubstitutedimidazoles," Catalysis Communications, Vol. 9, No. 10, 2008, pp. 2013-2017. doi:10.1016/j.catcom.2008.03.037

[29] J. Safari, S. D. Khalili and S. H. Banitaba, “A Novel and an Efficient Catalyst for One-Pot Synthesis of 2,4,5Trisubstituted Imidazoles by Using Microwave Irradiation Under Solvent-Free Conditions," Journal of Chemical Sciences, Vol. 122, No. 3, 2010, pp. 437-441. doi:10.1007/s12039-010-0051-6

[30] S. D. Sharma, P. Hazarika and D. Konwar, “An Efficient and One-Pot Synthesis of 2,4,5-Trisubstituted and 1,2, 4,5-Tetrasubstituted Imidazoles Catalyzed by $\mathrm{InCl}_{3} \cdot 3 \mathrm{H}_{2} \mathrm{O}$," Tetrahedron Letters, Vol. 49, No. 14, 2008, pp. 22162220. doi:10.1016/j.tetlet.2008.02.053

[31] A. R. Khosropour, "Ultrasound-Promoted Greener Synthesis of 2,4,5-Trisubstituted Imidazoles Catalyzed by $\mathrm{Zr}(\mathrm{acac})_{4}$ under Ambient Conditions," Ultrasonics Sonochemistry, Vol. 15, No. 5, 2008, pp. 659-664. doi:10.1016/j.ultsonch.2007.12.005

[32] F. K. Behbahani, T. Yektanezhad and A. R. Khorrami, "Anhydrous $\mathrm{FePO}_{4}$ : A Green and Cost-Effective Catalyst for the One-Pot Three Component Synthesis of 2,4,5Triarylated," Heterocycles, Vol. 81, No. 10, 2010, pp. 2313-2321. doi:10.3987/COM-10-12019

[33] V. S. V. Satyanarayana and A. Sivakumar, "An Efficient and Novel One-Pot Synthesis of 2,4,5-Triaryl- $1 \mathrm{H}$-imidazoles Catalyzed by $\mathrm{UO}_{2}\left(\mathrm{NO}_{3}\right)_{2} \cdot 6 \mathrm{H}_{2} \mathrm{O}$ under Heterogeneous Conditions," Chemical Papers, Vol. 65, No. 4, 2011, pp. 519-526. doi:10.2478/s11696-011-0028-Z

[34] W. M. Nelson, P. T. Anastas and T. C. Williamson, "Green Chemistry," Oxford University Press, Oxford,
1998, p. 200.

[35] K. Tanaka and F. Toda, "Solvent-Free Organic Synthesis,” Chemical Reviews, Vol. 100, No. 3, 2000, pp. 10251074. doi:10.1021/cr940089p

[36] J. H. Clark, “Solid Acids for Green Chemistry,” Accounts of Chemical Research, Vol. 35, No. 9, 2002, pp. 791-794. doi:10.1021/ar010072a

[37] A. Habibi, E. Sheikhhosseini, M. Bigdeli, S. Balalaie and E. Farrokhi, "Solvent Free Synthesis of $\alpha, \alpha$ '-Bis-(substituted-benzylidene)cycloalkanones Using Covalently Anchored Sulfonic Acid on Silica Gel $\left(\mathrm{SiO}_{2}-\mathrm{R}-\mathrm{SO}_{3} \mathrm{H}\right)$ as an Efficient and Reusable Heterogeneous" International Journal of Organic Chemistry, Vol. 1, 2011, pp. 143-147. doi:10.4236/ijoc.2011.14021

[38] N. C. Marziano, L. Ronchin, C. Tortato, S. Ronchin and A. Vavasori, "Selective Oxidations by Nitrosating Agents: Part 2: Oxidations of Alcohols and Ketones over Solid Acid Aatalysts," Journal of Molecular Catalysis A: Chemical, Vol. 235, 2005, pp. 26-34. doi:10.1016/j.molcata.2005.03.008

[39] A. K. Chakraborti, B. Singh, S. V. Chankeshwara and A. R. Patel, "Protic Acid Immobilized on Solid Support as an Extremely Efficient Recyclable Catalyst System for a Direct and Atom Economical Esterification of Carboxylic Acids with Alcohols,” Journal of Organic Chemistry, Vol. 74, No. 16, 2009, pp. 5967-5974. doi:10.1021/jo900614s

[40] J. Zhou, F. Chen, Q. B. Wang, B. Zhang, L. Y. Zhang and A. Yusulf, " $\mathrm{H}_{2} \mathrm{SO}_{4}-\mathrm{SiO}_{2}$ : Highly Efficient and Novel Catalyst for the Ferrier-Type Glycosylation," Chinese Chemical Letters, Vol. 21, No. 8, 2010, pp. 922-923. doi:10.1016/j.cclet.2010.03.013

[41] B. Roy and B. Mukhopadhyay, "Sulfuric Acid Immobilized on Silica: An Excellent Catalyst for Fischer Type Glycosylation,” Tetrahedron Letters, Vol. 48, No. 22, 2007, pp. 3783-3787. doi:10.1016/j.tetlet.2007.03.165

[42] B. Mukhopadhyay, "Sulfuric Acid Immobilized on Silica: An Efficient Promoter for One-Pot Acetalation-Acetylation of Sugar Derivatives," Tetrahedron Letters, Vol. 47, No. 26, 2006, pp. 4337-4340. doi:10.1016/j.tetlet.2006.04.118 